\title{
What Healthcare Workers Know about Covid-19 in Nowshera Pakistan
}

\author{
Hamzullah Khan* \\ Department of Pathology, Nowshera Medical College, Nowshera, Pakistan
}

*Corresponding author: Hamzullah Khan, Department of Pathology, Nowshera Medical College, Nowshera, Pakistan, E-mail: hamzakmc@ gmail.com

Received: 21 Apr, 2020 | Accepted: 04 May, 2020 | Published: 11 May, 2020

Citation: Khan H (2020) What Healthcare Workers Know about Covid-19 in Nowshera Pakistan. J Epidemiol Public Health Rev 5(2): dx.doi. org/10.16966/2471-8211.187

Copyright: (C) 2020 Khan H. This is an open-access article distributed under the terms of the Creative Commons Attribution License, which permits unrestricted use, distribution, and reproduction in any medium, provided the original author and source are credited.

Corona Virus disease termed as COVID-19 is an emerging highly contagious respiratory disease that is caused by novel corona virus. It was first reported from Wuhan China in December 2019. Its main clinical symptoms are fever, dry cough, fatigue, myalgia and dyspnea [1].

Case fatality rate of $2.3 \%$ has been reported from China that is lower than SARS (9.5\%), MERS (34.4\%) and H7N9 (39\%) [2].

To facilitate the management and administration of district Nowshera, of KP state of Pakistan to handle COVID-19, we feel a dire need to know the public and healthcare worker's awareness about 2019-nCoV, in this critical situation, therefore a KAP study was initiated.

We observed that $108 / 147$ (73.5\%) of the responders were of the opinion that they had knowledge about COVID-19 since 3 months of its first outbreak in China. $16.3 \%$ of the respondents were of the opinion to have been familiar with this virus since 1 month. In majority of the cases (93.2\%) the responders knew about the Corona virus outbreak through social media. For risk stratification we observed that $32 \%$ of the respondents were of the opinion that an immunity gap is a risk factor for acquiring COVID-19 infection. $18.4 \%$ of the responders attributed age less than 5 years and greater than 70 years at risk of acquiring this deadly infection.

$89.8 \%$ of the total strongly agreed that isolation and quarantine is the only precautionary measure and must be followed.

We also observed that $87 \%$ of the responders strongly agreed that all types of gatherings, celebrations, invitations in groups are dangerous for this pandemic disease.

The approach towards precautionary measures and treatment and denial of misconception like biological war, was more prevalent in the educated group with medical qualification.

The levels of understanding and the importance of isolation and social distancing are the key to contain this virus. China did very well by applying these measures. The National Health Commission of China issued protocols and guidelines with the slogan of "Big isolation and big disinfection" during the Chinese spring festival on $28^{\text {th }}$ Jan 2020 [3].
The New York Times also reported that the Corona virus is affecting more Italian males as compared to females in extremes of age because of their weak immune status. They further elaborated that Italian model of mortality is a trend mirror of what they observed in China with more casualties in male gender and at extremes of age [4].

China has taken measures in the province of Hubei, Wuhan Stat, including suspension of public transport, closing of recreation places, ban on social gathering and isolation and care of suspected cases in quarantine to succeed the fight against Corona virus [5].

It is concluded that the knowledge, attitude and practice of our health workers in understanding COVID-19 is acceptable and they are aware of the main precautionary measure to contain the virus. It is further suggested that all health workers should learn more about $2019 \mathrm{nCoV}$, its clinical presentation and precautionary measures to safeguard themselves and to save the community by increased surveillance of COVID-19 cases.

\section{References}

1. Chen N, Zhou M, Dong X, Qu J, Gong F, et al. (2020) Epidemiological and clinical characteristics of 99 cases of 2019 novel coronavirus pneumonia in Wuhan, China: a descriptive study. Lancet 395: 507513.

2. Munster VJ, Koopmans M, van Doremalen N, van Riel D, de Wit E (2020) A Novel Coronavirus Emerging in China-Key Questions for Impact Assessment. N Engl J Med 382: 692-694.

3. National Health Commission of People's Republic of China (2020) Notice on the issuance of a recent work plan for the prevention and control of pneumonia caused by new coronavirus infection.

4. Rabin RC (2020) In Italy, Coronavirus Takes a Higher Toll on Men. The New York Times.

5. Cascella M, Rajnik M, Cuomo A, Scott C Dulebohn, Raffaela Di Napoli (2020) Features, Evaluation and Treatment Coronavirus (COVID-19). StatPearls. 